\title{
Effect of Outreach on Financial Sustainability and Profitability of Saving and Credit Cooperatives in Eastern Ethiopia
}

\author{
Mekonnen Kumlachew (MSc.) \\ College of Business and Economics, Haramaya University
}

\begin{abstract}
This study scrutinized the effect of outreach on financial sustainability and profitability of SACCOs in Eastern Ethiopia using balanced panel data from 33 SACCOs over the period of 2017-2019. Quantitative approach and explanatory design was employed to realize the stated objective. This study used secondary data sources mainly audited financial statements of the SACCOs in the study period. The analysis revealed that SACCOs in Eastern Ethiopia are profitable but not financially sustainable. The random effect model result shows that gross loan to asset ratio, the yield on the gross loan portfolio, managerial and operational efficiency has a statistically significant and positive effect on the financial sustainability of SACCOs while average loan size has a statistically significant but negative effect. Likewise, gross loan to asset ratio, managerial efficiency, and average loan size has a statistically significant and positive effect on the profitability of SACCOs in Eastern Ethiopia. However, a portion of women borrowers and the number of active borrowers has a statistically significant but negative effect on the profitability of the SACCOs in the study area. Finally, the study suggests that increasing the number of borrowing clients and sales volume (loan portfolio) could benefit SACCOs in Eastern Ethiopia from the economics of scale. Keywords: Eastern Ethiopia, Financial sustainability, Outreach, Profitability, SACCOs
\end{abstract}

DOI: $10.7176 /$ RJFA/11-15-02

Publication date:August $31^{\text {st }} 2020$

\section{Introduction}

Access to safe and affordable financial services is recognized as a prerequisite for equitable socio-economic growth of a country. Continuous and sustained availability of finance at an affordable rate equips the poor and vulnerable ones with access to productive resources (physical as well as financial), and helps in smoothening consumption and setting up their business enterprises (Vijeta and Puja, 2019). However, conventional approaches to facilitate access to finance to the poor and vulnerable ones have not met successfully and they have failed to address the constraints in connection to finance.

According to Mori et al., (2009) the most important reasons for such exclusion by financial institutions is the presence of high transaction cost per borrower, lack of sufficient collateral to secure loan, information opacity, higher risk of default and low rate of cost recovery. As a result, the mainstream financial institutions commonly failed in financing and providing services tailored to the poor and microenterprises in most developing nations including Ethiopia.

In recent years, microfinance has emerged as an important tool to facilitate financial inclusion and has received attention from various socio-economic expertise, policymakers and institutions (Vijeta and Puja, 2019; Chiu, 2014; Tavanti, 2013 and Bruton et al., 2011). The cooperative movement has been regarded as being one of the financial mechanisms that can be used to improve financial accessibility for low-income entrepreneurs. In Ethiopia the delivery of financial products and services through micro-finance institutions like Saving and Credit Cooperative Societies (SACCOs) is one of the policy instruments used to enable rural and urban poor households and small enterprises to access deposit and credit facilities, which could improve productivity and increase income, thereby helping them to reduce poverty and attain food security (Muluneh, 2012 and Wolday, 2002). The authors argued that this could not be achieved by the banking system.

SACCOs are pro-poor financial cooperative institutions designed for the people, to have their own efficient financial service giving institutions based on the philosophy of building self-help society or "people helping people" that empowers themselves in asset building by teaching thrift culture and made credit easily accessible sustainably (Nalusiba, 2019; Melesse, 2018 and Getachew, 2006). The main target of SACCO is to mobilize savings from middle and low income groups and avail credit to the members at relatively lower interest rates compared to other financial institutions (Karimi, 2011). Additionally, SACCO's reach clients in rural and or poor areas, which do not have access to both private and government owned banks. This made them more attractive to customers since they largely demonstrate that the poor can borrow, pay substantial interest rates and save continuously in developing economies (Osoti, 2014 and Abate et al., 2013).

One of the strong comparative advantages of SACCOs is their ability to reach large number of people that are overlooked by formal financial institutions mainly banks. The contributing fact to the potential advantage from SACCOs is their ability to collect deposit from members and providing diversified loan to the members (Melesse, 2018 and Frank et al., 2015). Members are required to save regularly and encouraged to borrow for productive purposes out of the accumulated savings. Since both borrowers and depositors are members of SACCOs they are 
actively involved in creating and managing the demand and supply of loans (Melesse, 2018).

So as mentioned by Relampagos et al. (1990) and cited by Nigusie (2015), in terms of outreach, SACCOs are better than other formal financial institutions. Currently, there are 18,959 primary level SACCOs in Ethiopia, out of which 14,976 have been established in rural areas and 3,983 are in urban areas with a membership of 3,430,655 people out of which 1,358,119 are female and 2,072,536 are male members having 3.29 and 7.91 Billion birr capital and saving, respectively (FCA, 2017). This quantitative increment in number, membership, savings and loan disbursement calls for rigorous investigation of how outreach affects financial sustainability and profitability of SACCOs. SACCOs should be financially sustainable and profitable in order to provide sustainable financial services and contribute for poverty reduction.

Outreach is an indication of how SACCOs penetrate and provide quality financial services, as well as the volume of activities in the designated target society (Lafourcade et al. 2005). Okumu, (2007) described outreach as efforts to extend SACCOs' services to the people who are underserved by other financial institutions mainly banks. Outreach mainly incorporates breadth and depth dimensions, whereas the former one can be explained as the number of clients served and the volume of services delivered, while depth implies the socio-economic level of the clients that financial cooperatives reached (Okumu, 2007). Basically, increasing client outreach widens the financial services that are available to the cooperative members. Sustainability is the ability of a SACCOs to cover its operating and other costs from generated revenue and provide for profit. It is an indicator showing how the SACCOs stay financially viable even if subsidies and financial aids are cut off (Woolcock, 2006). In other words, it is the ability of an organization to meet its goals or target in the long run (Filene, 2011). The financial performance of SACCOs is an important indicator since it shows the sustainability of current outreach and the potential for additional outreach (Ssebaale, 2011 and Turto, 2008)

Theoretically, outreach to the poor and financial sustainability can be potentially either complementary or conflicting (Quayes, 2012). Once the institution becomes financially sustainable, it can wider outreach today, tomorrow and in the future (Frank et al., 2008). Meyer (2002) also noted that outreach and financial sustainability are complementary since the number of clients increases, microfinance institutions (MFIs) enjoy economies of scale and reduce production costs, which help them to become financially sustainable. On the other hand, Hulme and Mosely (1996), as cited by Abinet (2015) argued that there is inverse relationship between outreach and financial sustainability. They argued that higher outreach means higher transaction cost in order to get information about creditworthiness of clients and hence make MFIs financially unsustainable.

Evidence from Southern Tigrai of Ethiopia, Sebhatu (2011) concluded that there is a substantial growth in outreach and improvement of operational self-sufficiency of SACCOs. Toli (2013) examined the SACCOs' financial service in Addis Ababa and indicated that their outreach shows an increasing trend. Melesse (2018) also examined the sustainability and outreach performance of SACCOs in Eastern Ethiopia for the year 2016 and conclude that they are financially sustainable and their outreach performance is at moderate level. Based on the simple correlation result of his study, the outreach performance shows a negative and insignificant association with financial self-sufficiency.

Saxena and Guntram, (2018) reviewed financial performance of SACCOs in Tanzania, through their outreach and financial sustainability and the results of the study revealed that performance of SACCOs is good in terms of breadth outreach as it is reaching many rural dwellers and the sustainability indexes shows a positive trend approaching to1 implying that the SACCOs moved towards gaining sustainability in financial intermediation. Joseph, (2013) examined sustainability of rural SACCOs in Tanzania, and revealed that 46\% of them especially in Eastern and central zone were not sustainable because they accumulated large amount of nonperforming loan (NPL) and they did not issue new loans from 2006-2013. On the other hand, grants to total loans, cost per borrower, NPL to equity influenced the sustainability of rural SACCOs negatively while average loan size and age of SACCOs influenced sustainability positively. Nalusiba, (2019) also investigated the relationship between outreach and sustainability of SACCOs in Uganda and revealed that, sustainability is influenced by the number of borrowers since it provides more interest to the SACCOs, which could increase profitability and boosting sustainability in the long run that result into positive correlation between outreach and sustainability.

Various studies are also conducted on the relationship between outreach and financial sustainability of MFIs for instance; Abinet (2015) scrutinized the relationship between outreach and financial sustainability of those institutions in Ethiopia. He found significant and positive relationship between breadth of outreach, measured as number of active borrowers and gross loan to asset ratio, and financial sustainability and tradeoff between depth of outreach and financial sustainability. As per the findings of Befekadu (2007) on outreach and financial performance, MFIs are operationally sustainable measured in terms of return on asset and equity and the industry's profit performance is improving overtime.

Woller and Schreiner (2002) study the relationship between depth of outreach and financial self-sustainability and found positive causation. Paxton (2002) examined the relationship between depth of outreach and financial sustainability of MFIs (in Africa and Latin America) and found strong correlation between outreach and financial sustainability in Latin America and weak correlation in Africa. Cull et al. (2007) based on cross sectional study 
on MFIs in 49 countries concluded that there is possibility of increasing yield while serving economically active poor and thereby meeting both the social mission and viability.

The most comprehensive study of sustainability (measured by cost efficiency) and depth of outreach (measured by the average loan balance and percentage of women borrowers') trade-off is by Hermes, (2011) using data from 435 MFIs for the period 1997-2007, concluded that outreach is negatively related to sustainability. Although Olivares-Polanco (2005) study also confirms the existence of this trade-off. These findings are however inconsistent with Ayayi and Sene (2010) who shows that outreach and percentage of women among the clientele do not significantly influence the MFIs' financial sustainability. Their findings corroborated with Cull et al., (2007) that shows MFIs can expand outreach without compromising financial sustainability.

Okumu (2007) examined the determinants of sustainability and outreach of MFIs in Uganda and indicates that sustainability is negatively and significantly related to the ratio of gross loan outstanding portfolio to total assets. However, Tilahun (2013) reported that financial sustainability is positively and significantly influenced by the ratio of gross loan portfolio to total asset in east Africa. Quayes (2012) studied the depth of outreach and financial sustainability of MFIs (from Mix market) operating in 83 countries and found positive complementary relationship between financial sustainability and depth of outreach. However, Cheminingwa (2013), found depth of outreach was negative and significantly correlated with financial sustainability. On the other hand, breadth of outreach (numbers of borrowers) was found to be insignificantly related with financial sustainability in Kenya.

The literatures reviewed so far revealed that, studies conducted in Ethiopia were focused on the management, trends and determinates of SACCOs from the perspective of outreach and sustainability (Sebhatu, 2011; Toli, 2013 and Melesse, 2018). To the best knowledge of the researcher the effect of outreach on financial sustainability and profitability of SACCOs is not yet studied in Ethiopia. However, there are various studies carried out on the relationship between outreach and sustainability of MFIs in and outside Ethiopia even though there findings are contradictory (Abinet, 2015; Hermes, 2011; Cull et al., 2007; Olivares-Polanco, 2005; Woller and Schreiner, 2002 and Paxton, 2002), which surface an ongoing debate between breadth and depth of outreach for financial viability and sustainability. Therefore, this study seeks to add evidence to the limited empirical studies in the context of Ethiopia by investigating the effect of breadth, cost and depth of outreach and managerial and operational efficiency (control variables) on sustainability and profitability of SACCO's in Eastern Ethiopia.

According to USAID (2006) and Schreiner (2002), there are six aspects of outreach framework: the breadth, depth, length, scope and worth. However, some of these outreach factors may be difficult to measure since they require data that may not be easily available. Thus, this study examined only the effect of breadth, cost and depth of outreach proxies including managerial and operational efficiency (as control variables) on financial sustainability and profitability of SACCOs as shown in the figure 1 below.

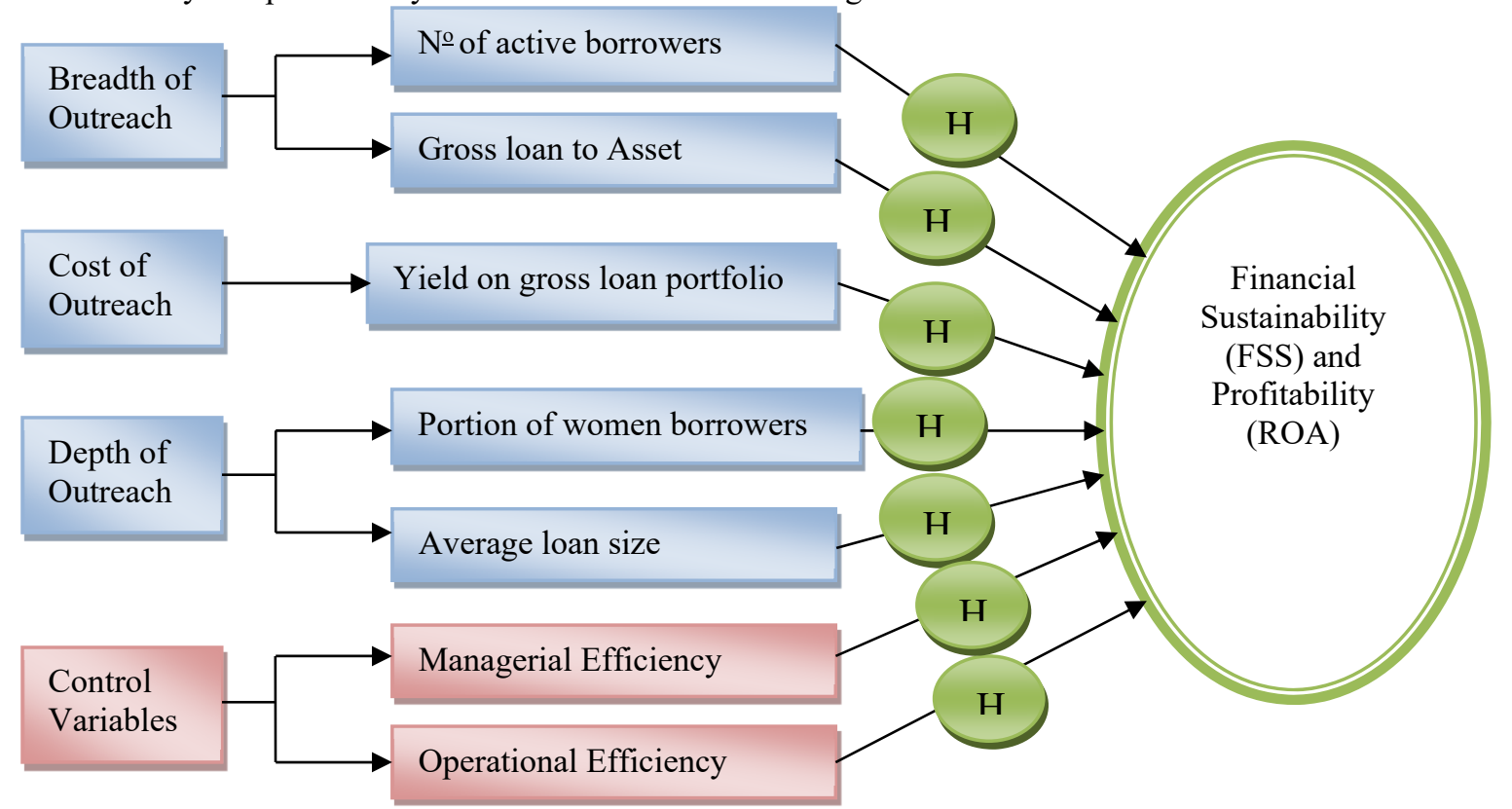

Source: Developed based on literatures and from Abinet (2015)

Figure 1. Theoretical model on the effect outreach on financial sustainability and profitability.

\section{Research Hypothesis}

Based on the empirical and theoretical studies reviewed this study developed and tested the following research hypotheses. 
$\mathrm{H}_{1}$. Number of active borrowers has positive and statistically significant effect on financial sustainability and profitability.

$\mathrm{H}_{2}$. Gross loan to asset ratio has positive and statistically significant effect on financial sustainability and profitability.

$\mathrm{H}_{3}$. Yield on gross loan portfolio has positive and statistically significant effect on financial sustainability and profitability.

$\mathrm{H}_{4}$. Proportion of women borrowers has positive and statistically significant effect on financial sustainability and profitability.

$\mathrm{H}_{5}$. Average loan size has positive and statistically significant effect on financial sustainability and profitability.

$\mathrm{H}_{6}$. Management efficiency has positive and statistically significant effect on financial sustainability and profitability.

$\mathrm{H}_{7}$. Operational efficiency has positive and statistically significant effect on financial sustainability and profitability.

\section{Materials and Methods}

This study attempted to evaluate effect of outreach on financial sustainably and profitability of SACCOs in eastern Ethiopia, particularly at Dire Dawa City Administration and East Hararghe zone. It is densely populated and drought prone part of the country, wherein majority of the people are poor (Melesse, 2018). To this effect, many SACCOs are organized with the support of NGOs and the government to break the poverty cycle.

In light of the research objective, the hypotheses developed and the quantitative nature of the data, this study has employed quantitative approach to investigate the effect of outreach on SACCO's financial sustainability and profitability. Accordingly, it has adopted an explanatory research design to realize the stated objectives. As noted by (Kothari, 2008), explanatory research design examines the cause and effect relationships between dependent and independent variables.

The total populations of SACCOs found and operated in the study area, eastern Ethiopia are 395. However, due to limited capacity of the supervisory body and the SACCOs themselves majority of them have not been audited annually. However, 33 SACCOs were audited for the last three consecutive years from 2017 to 2019 , which guaranteed to consider those SACCOs in this study. Thus, the study considered SACCOs operating at least for more than three years and has complete audited financial statements for three consecutive years.

This circumstance implies that the study used a purposive sampling technique when selecting only SACCOs which are active, complete three years of operation and have audited financial statement over the study period since most of the SACCOs in the area are not audited annually.

\subsection{The Data Type and Source}

The study used secondary data collected from annual audited financial statements of sampled SACCOs, which have been collected from concerned government bodies (East Hararghe Zone and Dire Dawa City Administration cooperative promotion office) through document review to increase reliability of the data. The data were strongly balanced panel type, which captured both cross-sectional and time series behaviors.

\subsection{Methods of Data Analysis}

The study used both descriptive statistics and econometric tools to analyze the data and address the predefined objective. The former one includes simple descriptive methods such as: mean, maximum, minimum, standard deviations and other simple statistical tools that enable to better understand the existing situation and analyze the general trends of the data. The study substantiated the descriptive analysis through manipulating econometric models to examine causal relationship between the explanatory and dependent covariates. In this regard, the study employed Random Effect Model to identify the explanatory variables that significantly affecting financial sustainability and profitability of SACCOs.

\subsection{Definition and Measurements of Variables}

\subsubsection{Dependent variables}

The dependent variables in this study were financial sustainability and profitability of SACCOs, which were measured by financial self-sufficiency (FSS) and return on asset (ROA). The FSS was measured as the ratio of Adjusted Operating Income to Adjusted Operating Expenses, which is the sum of financial, operating and loan loss provision expense. The adjustment was crucial to show the true financial picture of an institution on an unsubsidized basis, where funds would be raised on the commercial market, rather than through donor grants or subsidized capital (Marwa, 2015). Financial sustainable SACCOs are profitable enough to maintain and expand its services without continued injections of subsidies or donor funds (World Bank, 2003). In short, FSS ratio can be computed as follows:- 
$F S S=\frac{\text { Adjusted Financial Revenue }}{}$

In order to measure profitability of financial institutions different ratios may be used. The commonly used ratios are Return on Assets (ROA) and Return on Equity (ROE) (Nyamsogoro, 2010; Tucker and Miles, 2004). Due to data limitation, this study used the former one i.e. ROA to measure profitability of SACCOs. Return on Assets (ROA) measures the overall profitability and reflects both the profit margin and how the institution is efficient in using the total assets to generate revenue (Brealey et al., 2006). ROA is calculated as the ratio of the net income to the total assets.

$R O A=\frac{\text { Net Income }}{\text { Average Total Asset }}$

\subsubsection{Independent variables}

According to Microfinance Information Exchange (MIX) (2010), loan outreach can be assessed by an annual comparative analysis through measurement of several variables including number of active borrowers and gross loan portfolio as a proxy of breadth and average loan balance per borrower and percentage of woman borrowers as a proxy of depth of outreach. Likewise, previous studies (Abinet, 2015; Nara, 2013; Zerai and Rani, 2012 and Meyer, 2002) used similar indicators in their framework, for measuring microfinance outreach. Tilahun (2013) and Okomu (2007) were also among others who used gross loan to total asset ratio to measure breadth of outreach. Moreover, Gashaw (2014) and Millson (2013) included yield to gross loan portfolio in their models as cost of outreach indicator. Following this convention, this study also used all the loan outreach indicators including managerial and operational efficiency as a control variable to measure the effect of outreach indicators on financial sustainability and profitability of SACCOs in Eastern Ethiopia. Table 1 presents the summary of variables and their expected effect on the dependent variable. Some of the variables were computed to their log form for compatibility of the regression.

Table 1. Summary of variables and their expected relationship

\begin{tabular}{|c|c|c|c|}
\hline Category & Variable Name & Measurement / proxies used & $\begin{array}{l}\text { Expected } \\
\text { Effect }\end{array}$ \\
\hline \multirow{2}{*}{ 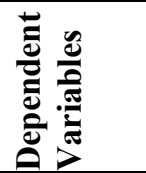 } & $\begin{array}{l}\text { Financial Sustainability } \\
\text { (FSS) }\end{array}$ & \multicolumn{2}{|l|}{$\begin{array}{l}\text { Adjusted operating income to adjusted operating } \\
\text { expenses }\end{array}$} \\
\hline & Return on Asset (ROA) & Net Income/ Total Asset & \\
\hline \multirow{7}{*}{ 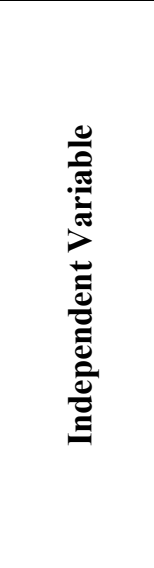 } & $\begin{array}{l}\text { Number of } \\
\text { borrowers }(\mathrm{NAB})\end{array}$ & Natural logarithm of (Number of active borrowers) & + \\
\hline & $\begin{array}{l}\text { Gross loan to Asset ratio } \\
\text { (GLA) }\end{array}$ & Gross loan portfolio/ Total Asset & + \\
\hline & $\begin{array}{l}\text { Yield on gross loan } \\
\text { portfolio (GPY) }\end{array}$ & Financial revenue / Gross Loan Portfolio & + \\
\hline & $\begin{array}{l}\text { Portion of } \quad \text { women } \\
\text { borrowers (PWB) }\end{array}$ & $\begin{array}{l}\text { Number of active women borrowers/ Total number of } \\
\text { active borrowers }\end{array}$ & $+/-$ \\
\hline & Average loan size (ALS) & $\begin{array}{l}\text { Natural logarithm of (Gross Loan Portfolio /Number } \\
\text { of Active borrowers) }\end{array}$ & $+/-$ \\
\hline & $\begin{array}{l}\text { Managerial Efficiency } \\
\text { (MGE) }\end{array}$ & Operating Expense/Operating Income & + \\
\hline & $\begin{array}{l}\text { Operational Efficiency } \\
\text { (OPE) }\end{array}$ & Cost/ Income & + \\
\hline
\end{tabular}

Source: Developed based on the literatures

To identify effect of outreach indicators on sustainability and profitability of SACCOs this research formulated the following econometric models.

$$
\begin{aligned}
& F_{S S}=\alpha+\beta_{1}(N A B)_{i t}+\beta_{2}(G L A)_{i t}+\beta_{3}(G P Y)_{i t}+\beta_{4}(P W B)_{i t}+\beta_{5}(A L S)_{i t}+\beta_{6}(M G E)_{i t}+\beta_{7}(O P E)_{i t} \\
& +\varepsilon_{i t} \\
& R O A_{i t}=\alpha+\beta_{1}(N A B)_{i t}+\beta_{2}(G L A)_{i t}+\beta_{3}(G P Y)_{i t}+\beta_{4}(P W B)_{i t}+\beta_{5}(A L S)_{i t}+\beta_{6}(M G E)_{i t}+\beta_{7}(O P E)_{i t} \\
& +\varepsilon_{i t}
\end{aligned}
$$

Where, FSS is the Financial Sustainability, ROA is the Return On Asset, NAB is the Number of Active Borrowers (breadth of outreach), GLA is the Gross Loan portfolio to Asset ratio (breadth of outreach), GPY is the Yield on Gross Loan Portfolio (cost of outreach), PWB is the Portion of Women Borrowers (depth of outreach), ALS is the Average Loan Size (depth of outreach), MGE is the Managerial Efficiency (control variable) and OPE 
is the Operational Efficiency (control variable), $\mathrm{i}$ is the $\mathrm{i}^{\text {th }} \mathrm{SACCO}$, $\mathrm{t}$ is the time period, $\beta_{1}, \beta_{2}, \beta_{3}, \beta_{4}, \beta_{5}, \beta_{6}$ and $\beta_{7}$ are the coefficients for each independent variables in the model, $\varepsilon_{i t}$ is the error term.

\section{Result and Discussion}

\subsection{Descriptive result}

The value greater than $105 \%$ for financial sustainability indicates that, SACCOs are financially self-sufficient and the value below this point indicated that they are not self-sufficient (WOCCU, 2011). As indicated in the Table 2, the average value of financial sustainability is $0.69(69 \%)$ which is below the breakeven/threshold level for financial sustainability. The result depicted that, the sample SACCOs in the study period was not financially sustainable and the sector cannot be self-reliant without external assistant like donors and subsidies from the concerned body. Meyer, (2002) argued that many SACCOs have been unsustainable for various reasons, which is a finding against Melesse, (2018) in the same study area on similar issue. The maximum and minimum value of this variable are $1.30(130 \%)$ and $0.15(15 \%)$, respectively (see Table 2$)$. The result shows that, the financial sustainability of sampled SACCOs over the study period ranges from $15 \%$ (too much dependence on donation and subsidies) to $130 \%$ (financially self-sufficient). Its standard deviation is $0.299(30 \%)$, illustrates the disparity of financial sustainability among sampled SACCOs in the study area.

Return on asset is a ratio of net income and average total asset, which measures the amount of profit generated per birr of investment in assets. The ratio of $10 \%$ and above indicates that the SACCOs are profitable and have the capacity to build institutional capital (WOCCU, 2011). According to Table 2, the average value of SACCOs' profitability is $0.76(76 \%)$, which is above the breakeven/threshold level of profitability, which indicates that the sampled SACCOs on average earned a profit of 0.76 cents from one birr invested in their asset during the study period. The maximum value of the return on asset is $1.25(125 \%)$ and the minimum value is $0.19(19 \%)$. This shows that profitable SACCOs earned 1 birr and 25 cents of profit for a birr invested on assets. On the other hand, the least profitable SACCOs earned 19 cents of profit for each birr invested in their assets during the study period. The standard deviation of 0.28 (28\%) indicates the disparity of SACCO's profitability performance. Table 2. Descriptive statistics for the dependent variables

\begin{tabular}{llllll}
\hline Variable & Obs $=99$ & Mean & Std. Dev. & Min & Max \\
\hline FSS & & 0.6913 & 0.2994 & 0.1466 & 1.3086 \\
ROA & 0.7630 & 0.2773 & 0.1908 & 1.2512 \\
\hline
\end{tabular}

Number of active borrowers (NAB) measures the extent of providing financial services to the low income or underserved clients. As indicated in Table 3, the average value of active borrowers served is 4.20 in its $\log$ value which is equal to $15,973.5$ borrowers in its real value. The MIX benchmark classifies the breadth of outreach as large (greater than 30,000 number of borrowers), medium (10,000-30,000 number of borrowers), and small if less than 10,000 number of borrowers (Bayeh, 2012). Thus, the breadth of outreach for sampled SACCOs in the study area is medium with average borrowers of 15,974 individuals. The maximum and minimum values of this variable are 7.09 and 2.99 (about 12,302,688 and 990 active loan clients), respectively with the standard deviation of 0.738 (about 6).

Gross loan portfolio to asset (GLA) measures the amount of asset invested on gross loan portfolio. The higher gross loan to asset ratio indicates most of the institution's funds are invested on client as a loan, which increase outreach to the poor. The average value of this variable is $1.06(106 \%)$, which indicates that sample SACCOs invested $106 \%$ of their asset on gross loan portfolio during the study period. The maximum and minimum value of this variable is $2.71(271 \%)$ and $0(0 \%)$, respectively with the standard deviation of $0.53(53 \%)$

Yield on gross loan portfolio (GPY) indicates the efficiency of SACCOs in generating cash revenue out of its resources. As per the WOCCU's standard, SACCOs are expected to earn at least $10 \%$ income on their loan disbursed to their members. Table 3 indicates that sampled SACCOs generate 0.058(5.8\%) income from the loan given to the customers during the study period. The result shows that sampled SACCOs are not generating enough amount of income that covers their operating and financial costs. The maximum yield on the gross loan portfolio for this study is $0.1(10 \%)$, which is equal to the expected level as to WOCCU's. However, SACCOs in the study area, as they are earning too low rate of return, their sustainability and profitability potential are in question.

Portion of Women Borrowers (PWB) indicates the percentage of women borrowers to total borrowers. The higher the percentage is, the higher the depth of outreach, wherein SACCOs in this study has an average value of $0.65(65 \%)$, which implies that sampled SACCOs in the study area provides $65 \%$ of loan to women's members. The maximum and minimum value of this variable is $1(100 \%)$ and $.071(7.1 \%)$, respectively. This shows that some of the sampled SACCOs provide up to $100 \%$ of loan to women beneficiaries.

Average Loan Size (ALS) shows the average value of 8.69 in its log value equal to 4.92 Million Ethiopian Birr, which is the average loans size of SACCOs to the number of active borrowers during the study period. The maximum and minimum values of this variable are 10.32 and 5.85 in its natural logarithm value which is equal to 20 Billion and 702,101.7 Birr, respectively with the standard deviation value of 0.89 in its natural logarithm implying SACCOs in the sample varying in loan size. 
Managerial Efficiency is the ratio of operating income to expense. Based on the descriptive result, the mean value of managerial efficiency is $0.70(70 \%)$, which indicates that on average the sampled SACCOs incurred 0.70 cents operating costs like salaries, supplies, loan losses, and other administrative costs to generate one birr operating income during the study period. The maximum and minimum value of managerial efficiency is $1.31(1.31 \%)$ and $0.19(19 \%)$ respectively, with a standard deviation of 0.28 . The minimum value shows that managerially efficient SACCOs incurred operating cost of 0.19 cent to generate one birr operating income. On the other hand, managerially less efficient SACCOs incurred operating cost of 1birr and 31cents to generate one birr operating income, which result into lose of 31 cents.

Operational Efficiency is the ratio of cost to income. Based on the descriptive result, the mean value of operational efficiency of SACCOs is $0.96(96 \%)$ indicating that on average sampled SACCOs incurred 0.96 cents total cost/expense/ to generate one birr total income/revenue/ during the study period. The maximum value of operating efficiency is $1.71(171 \%)$ and the minimum value of $0.59(59 \%)$ with a standard deviation of 0.18 . The minimum value indicates that operationally efficient SACCOs incurred cost of 0.59 cent to generate one birr income. On the other hand, operationally least efficient SACCOs incurred cost of 1birr and 71cents to generate one birr income during the study period.

Table 3. Descriptive statistics for the independent variables

\begin{tabular}{|c|c|c|c|c|c|}
\hline Variable & Obs $=99$ & Mean & Std. Dev. & Min & Max \\
\hline NAB & & 4.2035 & 0.7384 & 2.9957 & 7.0900 \\
\hline GLA & & 1.0648 & 0.526 & 0 & 2.7082 \\
\hline GPY & & 0.0587 & 0.0228 & 0 & 0.10 \\
\hline PWB & & 0.6533 & 0.2544 & 0.0714 & 1.00 \\
\hline ALS & & 8.6922 & 0.8946 & 5.8465 & 10.316 \\
\hline MGE & & 0.7058 & 0.2832 & 0.1974 & 1.3086 \\
\hline OPE & & 0.9646 & 0.1798 & 0.5862 & 1.7119 \\
\hline
\end{tabular}

\subsection{Regression Result}

Effect of Outreach on Financial Sustainability (FSS)

Table 4 presents the random effect regression results to indentify effect of outreach on financial sustainability of SACCOs in eastern Ethiopia. The variables included in the model explained about $85 \%$ of the total variation on financial sustainability which is reasonably a good fit. This implies that the explanatory variables (such as, number of active borrowers, gross loan to asset, yield on gross loan portfolio, percentage of women borrowers, average loan size, operational and managerial efficiency) jointly explained about $85 \%$ of the total variation in the financial sustainability.

The regression result indicates that gross loan to asset, yield on gross loan portfolio, managerial and operational efficiency has statistically significant and positive effect on the financial sustainability of SACCOs in Eastern Ethiopia. However, average loan size has statistically significant and negative effect on the financial sustainability of SACCOs as to the model result on Table 4.

Gross loan to asset ratio is a proxy for breadth of outreach, which indicates the amount of assets SACCOs investment on gross loan portfolio. The higher gross loan to asset ratio indicates that most of the institution's funds are invested on client as a loan, which enhances outreach to the poor. The model result reveals that gross loan to asset ratio and financial sustainability has positive and statistically significant relationship at 5\% significant level. The gross loan portfolio investment is the main source of income for SACCOs, which infers that higher loan disbursed may guarantee better interest revenue and profit, which may secure financial sustainability. The result is consistent with the findings of Abinet, (2015), Tilahun, (2013) and Cull et al., (2007) who reported statistically significant and positive relationship between loan intensity (gross loan to asset ratio) and MFIs financial self sufficiency. However, this result contradicts with findings of Okumu, (2007), who documented a negative causation between loans to asset ratio and MFI's sustainability. Based on the model result on Table 4 it is easy to conclude that the relationship between breadth of outreach as measured by loan intensity and financial sustainability is positive and statistically significant.

Yield on gross loan portfolio is a proxy measure for interest rates charged by SACCOs to loan disbursed to clients mostly their members. The result shows that yield and financial sustainability has statistically significant and positive relationship (see Table 4). This implies that when the interest rate on client's loan increases then SACCOs could generate better interest income and financial sustainability could be enhanced. This finding corroborated with Gashaw, (2014), Cull et al., (2007) and Woller and Schreiner, (2002) found statistically significant and positive relationship between financial sustainability and yield from gross loan. They have argued for the possibility of better yield thereby meeting both the social mission and viability given that the clients are economically active poor. As per the result, an increase in yield lead to improved financial sustainability without compromising outreach.

A managerial efficiency ratio is a financial ratio designed to measure the efficiency of management in using its 
assets (working capital or other resources) and managing its liabilities effectively in the short-run. The model result indicates managerial efficiency has positive and statistically significant effect on financial sustainability of SACCOs. It is expected that, when a firm has better managerial efficiency (the lower ratio), the firm is either getting more income with a determined level of resources or incurring less expenses that in turn leads to improved profitability and sustainability of SACCOs (Velery, 2018). The result substantiated with the findings of Habtamu (2012) and Mwaura (2005), the better the management's efficiency in utilizing the available resources the higher the financial performance that results into sustainability of SACCOs. Likewise, Operational Efficiency is another performance measure used as an indicator of management's ability to control the cost and how well SACCOs are reform there operations and takes into account the cost of the input and/or the price of output in maximizing income. The model result on Table 4 indicates that the coefficient of the operational efficiency is positive and statistically significant at $10 \%$ significance level. The result shows that minimizing costs would certainly improve SACCO's financial sustainability. This result is consistent with the findings of Melesse, (2018), Marwa, (2015), Kinde, (2012) and Nyamsogoro, (2010). These all imply that an increment in managerial and operational efficiency (controlling cost) increases the financial sustainability of SACCOs.

Average loan size is a proxy for depth of outreach, which indicates the average loan size per the number of borrowers. It is generally perceived, the smaller its size (smaller loans) indicates greater depth of outreach (Cull et al., 2007). However, MFIs offering small size loan with shorter maturity attract high transaction costs, which experiences declining sustainability and profitability (Lupenu and Zeller, 2002). Average loan size has negative and statistically significant effect on financial sustainability of SACCOs as presented on Table 4. This indicates that SACCO's success is associated with smaller loan sizes since it is significantly correlated with the borrower's poverty level (Schreiner, 2002). The result is consistent with the result of Abinet, (2015) and Nyamsogoro, (2010); who argued that MFIs success should be measured based on the depth of their outreach (how many poor clients they are able to reach). However, the result is inconsistent with the finding of Joseph, (2013); Quayes, (2012); Ganka, (2010) and Cull et al., (2007) who conclude profitability relates selling bigger loans sizes, evidence for the strong tradeoff between serving the poor and being financially sustainable.

Table 4. Random effect model result for identifying determinants of FSS

\begin{tabular}{llll}
\hline Explanatory variables & Coefficient & Std. Err. & Z-value \\
\hline NAB & -0.0179 & 0.0203 & -0.88 \\
GLA & $0.0638^{* *}$ & 0.0321 & 1.99 \\
GPY & $1.6638^{* * *}$ & 0.6145 & 2.71 \\
PWB & -0.0149 & 0.0531 & -0.28 \\
ALS & $-0.0356^{* *}$ & 0.0172 & -2.07 \\
MGE & $1.0113^{* * *}$ & 0.0481 & 21.06 \\
OPE & $0.1319^{*}$ & 0.0694 & 1.90 \\
Constant & 0.0790 & 0.1663 & 0.48 \\
\hline $\mathrm{R}^{2}$ Within & 0.8563 & \\
$\mathrm{R}^{2}$ Between & 0.9089 & & \\
$\mathbf{R}^{2}$ Overall & 0.8523 & \\
sigma_u & 0.00 & \\
sigma_e & 0.12 & \\
Prob $>\chi^{2}$ & 0.0000 & \\
$* * *$ and** implies significant at 1 and 5\% level of significance, respectively.
\end{tabular}

*** and $* *$ implies significant at 1 and $5 \%$ level of significance, respectively.

Source: Own computation, 2020

Effect of Outreach on profitability (ROA)

Table 5 presents the random effect regression results to identify the effect of outreach on profitability of SACCOs in Eastern Ethiopia. The variables included in the model explained about $64 \%$ of the total variation of profitability scores, which is reasonably a good fit. This implies that the explanatory variables (such as, number of active borrowers, gross loan to asset, yield on gross loan portfolio, portion of women borrowers, average loan size, managerial and operational efficiency) jointly explained about $64 \%$ of the total variation in the profitability.

The regression result of the analysis indicates that gross loan to asset, managerial efficiency and average loan size has statistically significant and positive effect on the profitability of SACCOs. However, proportion of women borrowers and number of active borrowers has statistically significant and negative effect on the profitability of SACCOs as to the model result on Table 5.

The model result shows that gross loan to asset and profitability has positive and statistically significant relationship. The gross loan portfolio is the main source of income to SACCOs as a result; higher loan disbursement would result into better interest revenue and profits. The result is consistent with the findings of Kipesha and Zhang (2013) and Cull et al., (2007) that found gross loan to asset statistically significant variable as determinants of financial performance. However, Tilahun (2013) argues that MFIs risk increases when its loan to asset ratio increases, and profitability may decrease. Based on Table 5 an increase in the ratio of gross loan to asset 
increases the profitability of SACCOs.

The model result on table 5 indicates that managerial efficiency has positive and statistically significant effect on profitability of SACCOs. The result shows that, the higher the managerial efficiency in utilizing the available resources the higher the profitability. This output corroborated with the findings of Habtamu (2012) and Mwaura (2005) that found a significant and positive relationship between management efficiency and profitability.

Based on the model result, the effect of average loan size is positive and statistically significant at $10 \%$ significant level. This indicates that SACCO's profitability is associated with higher loan sizes since larger loan is associated with better cost efficiency and there is nothing to worry about default risk in SACCOs given that it is $100 \%$ secure through own saving and members guarantor. The model result is consistent with the findings of Ganka (2010) and Schreiner (2002) argued that SACCOs will be unable to sustain their operations without profits and conclude that profitability strongly related to disbursing larger loans, which was supported by Adhikary and Papachristou (2014) and Paxton (2002) found that a positive relationship with profitability. As per the result, an increase in managerial efficiency and average loan size increases the profitability of SACCOs.

As to the model result on Table 5, portion of women borrowers has negative and statistically significant effect on profitability of SACCOs. This finding is consistent with the findings of Kipesha and Zhang (2013) and Oliveres-polanco (2005) reported negative and significant relationship between percentage of women borrowers and MFIs profitability, but in contradiction with the findings of Adhikary and Papachristou (2014) and Paxton (2002) found that depth of outreach is positively related to profitability. Likewise, number of active borrowers has negative and statistically significant effect on profitability, which is supported by the finding of Cheminingwa (2013) and Ganka (2010) reported a negative relationship between number of borrowers and profitability as inefficiency increases as a result of increased number of borrowers but against with Nalusiba (2019) found increased number of borrowers generates more interest to SACCOs hence increasing profitability and boosting sustainability in the long run. As per a result, an increase in portion of women borrowers and number of active borrowers decrease the profitability of SACCOs in Eastern Ethiopia.

Table 5. Random effect model for identifying determinants of ROA

\begin{tabular}{llll}
\hline Explanatory Variables & Coefficient & Std. Err. & Z-Value \\
\hline NAB & $-0.049^{*}$ & 0.0295 & -1.66 \\
GLA & $0.3222^{* * *}$ & 0.0466 & 6.91 \\
GPY & 0.9123 & 0.8918 & 1.02 \\
PWB & $-0.2257^{* * *}$ & 0.077 & -2.93 \\
ALS & $0.0444^{*}$ & 0.0249 & 1.78 \\
MGE & $0.5653^{* * *}$ & 0.0697 & 8.11 \\
OPE & -0.0096 & 0.1007 & -0.10 \\
cons & -0.0562 & 0.2414 & -0.23 \\
\hline $\mathrm{R}^{2}$ Within & & \\
$\mathrm{R}^{2}$ Between & 0.6396 & \\
$\mathbf{R}^{2}$ Overall & 0.2812 & \\
sigma_u & 0.6374 & \\
sigma_e & 0.00 & & \\
Prob $>\chi^{2}$ & 0.17 & \\
*** and** implies significant at 1 and 5\% level of significance, respectively. \\
Source: Own computation, 2020
\end{tabular}

\section{Conclusions and Recommendations}

\subsection{Conclusions}

Based on the findings from the descriptive analysis, SACCOs in Eastern Ethiopia were profitable but not financially sustainable during the study period. This implies that, SACCOs are not self-reliant without external assistant like donors and subsidies. As per the model result, it is easy to conclude that financial sustainability and profitability of SACCOs best explained by the explanatory variables included in the model.

The findings demonstrate that; gross loan to asset, yield on gross loan portfolio, managerial and operational efficiency has statistically significant and positive effect on the financial sustainability, which indicates that an increase in those variables result into a better financial sustainability. However, average loan size has significant negative effect on the financial sustainability of SACCOs in Eastern Ethiopia.

Besides, it can be conclude that, gross loan to asset, managerial efficiency and average loan size has significant positive effect on the profitability. However, portion of women borrowers and number of active borrowers has significant negative effect on the profitability of SACCOs in Eastern Ethiopia.

Furthermore, this study also concludes that outreach and financial sustainability and profitability of SACCOs are complimentary since there is no evidence of trade-off between them. Thus, SACCOs should work to achieve both outreach and financial sustainability and profitability at the same time. 


\subsection{Recommendations}

Based on the findings, the study forwarded the following operational and policy recommendations

It is recommended that SACCOs should augment their self-sufficiency while serving the poor through increasing amounts of asset invested to loan, yield on gross loan, improving their managerial and operational efficiency.

SACCOs have to improve their returns by charging appropriate interest rate on loans to cover operational, financial and other administrative costs, expand its services and utilizing their available resources to the possible maximum level to sustain as alternative financial service provider.

SACCOs should increase gross loan portfolio investment (volume of sale) and decrease the amount of loan size disbursed to serve large number of borrowers to be benefited from the economics of scale since the total cost will be distributed over the large number of borrowers and volumes of outputs that will reduce cost of production. Thus, the higher the loan and number of borrowers enhances the interest revenue and financial sustainability.

SACCOs should also give education and training to members on credit utilization and management in order to increase loan demand and invest the loan into productive area.

SACCOs have to work on improving women members benefit from their service since women traditionally lack access to finance and generally represented among the hard core-poor. Women borrowers have high repayment rates on loans. Thus, the focus on more women clients increases the chances for low repayment rates leads to less default risk, higher profit and hence improved financial sustainability.

SACCOs have to improve their operational and managerial efficiency through providing continuous training and information management committee members and hiring high caliber managers in the field to bring good governance and better financial management to remain competitive, profitable and sustainable.

Finally, all the government bodies in charge of cooperative at various levels should pay great attention through continuously supervising, inspecting, auditing and developing regulatory environment to modernize the financial system and make them financially prudent and viable financial institutions highly contribute for the outreach of financial services for the country.

\section{References}

Abate G. T., Borzaga C., and Getnet K. (2013). Financial sustainability and outreach of microfinance institutions in Ethiopia: does organizational form matter? Euricse Working Paper, no. 56.

Abinet Yeshi (2015). The Relationship between Outreach and Financial Sustainability: An Empirical Study on Ethiopian Microfinance Institutions: unpublished thesis submitted to Addis Ababa University.

Adhikary, S. and Papachristou, G. (2014). Is there a trade-off between financial performance and outreach in South Asian microfinance institutions? The Journal of Development Areas 48(4): 381-402

Ayayi, A and Sene, M (2010). What drives microfinance institution's financial sustainability? The Journal of Developing Areas, vol 44, pp. 303-324.

Bayeh Asnakew Kinde (2012). Financial Sustainability of Microfinance Institutions (MFIs) in Ethiopia ${ }^{e e}$, European Journal of Business and Management, 4(15), pp. 001-010.

Befekadu B. Kereta (2007). Outreach and Financial Performance analysis of Microfinance Institutions in Ethiopia, paper presented on African Economic Conference United Nations Conference Center (UNCC), Addis Ababa, Ethiopia.

Brealey, RA, Myers, SC and Allen, F. (2006). Corporate Finance, London.

Bruton, G. D., Khavul, S., and Chavez, H. (2011). Micro lending in emerging economies: building a new line of inquiry from the ground up. Journal of International Business Studies, 42(5), 718-739.

Cheminingwa (2013). The relationship between MFI outreach services and financial sustainability in Kenya

Chiu, T. (2014). Putting responsible finance to work for Citi microfinance. Journal of Business Ethics, 119(2), $219-234$

Cull, R., Demirgüç-Kunt, A. and Morduch, J. (2007). Financial performance and outreach: A global analysis of leading micro banks. The Economic Journal, 117, 107-133.

Filene, (2011). Credit Union Financial Sustainability: A Colloquium at Harvard University, Filene Research Institute Report Number 231.

Frank, T., Mbabazize, M., and Shukla, J. (2015). Savings and credit cooperatives (SACCO's) services' terms and members' economic development in Rwanda: A case study of zigama SACCO ltd. International Journal of Community and Cooperative Studies, 3(2).

Ganka, D. (2010). Financial sustainability of rural microfinance institutions in Tanzania. PHD thesis, University of Greenwich, Australia.

Gashaw (2014). Microfinance in Kenya, Uganda and Ethiopia: loan outreach to the poor and the quest for financial viability.

Getachew Mergia (2006). Sustainable SACCO Development Training Material. Uganda: USAID.

Habtamu. (2012). Determinants of bank profitability: an emperical study on Ethiopian private commercial banks, 
MSC project paper, Addis Ababa University.

Hermes N., Lensink, R. and Meesters A. (2011). Outreach and efficiency of microfinance institutions. World Development, 39 (6), 938-948.

Joseph John Magali (2013). Are Rural SACCOS in Tanzania Sustainable? International Journal of Management Sciences and Business Research, 2013 ISSN (2226-8235) Vol-3, Issue 1

Karimi KC (2011). The role of savings and credit cooperative societies in facilitating rural financing in Kenya (a case study of Embu County). Master's Thesis. The University of Nairobi, 2011. http://erepository.uonbi.ac.ke:8080/handle/123456789/6072

Kinde, B.A. (2012). Financial Sustainability of Microfinance Institutions (MFIs) in Ethiopia. European Journal of Business and Management, 4(12), 2012.

Kipesha, E. and Zhang (2013). Sustainability, Profitability and Outreach Tradeoffs: Evidences from Microfinance Institutions in East Africa.

KK Saxena and Guntram M Wagofya (2018). Statistical analysis of outreach and financial sustainability of kifanya Saccos limited in Njombe. International Journal of Statistics and Applied Mathematics 2018; 3(6): 119-123

Kothari, C. (2008). Research Methodology: Methods and techniques. New Delhi, India: New age international publication.

Lafourcade, A., Isern, J., Mwangi, P. and Brown, M. (2005). Overview of the outreach and financial performance of microfinance institutions in Africa. MIX, 2005.

Lupenu, C., and Zeller, M. (2002). Growth, and performance of the microfinance institutions in Africa, Asia and Latin America: a recent inventory. Savings and Development, 1(26), 87.

Marwa, N. (2015). Financial sustainability of Tanzanian saving and credit cooperatives. Presented at REPOA'S $19^{\text {th }}$ annual research workshop. Dar es salaam, Tanzania.

Melesse Semaw Henock (2018). Financial sustainability and outreach performance of saving and credit cooperatives: The case of Eastern Ethiopia. Asia Pacific Management Review 24 (2019) 1-9

Meyer, J. (2002). Track record of financial institutions in assessing the poor in Asia. ADB research institute paper, No. 49, September 30, 2011

Millson, H. F. (2013). The Trade-Off between Sustainability and Outreach: The Experience of Commercial Microfinance Institutions.

MIX. (2010). MIX (microfinance information exchange), 2010, descriptive microfinance performance bench marks; from http://www.mixmarket.org/

Mori, N, Richard, E, Isaack, A and Olomi, D. (2009). Access to Finance for SMEs in Tanzania. In Olomi, D (Ed.), African Entrepreneurship and Small Business Development: Context and Process (Vol. 1), Otme Company Ltd., Dar es Salaam.

Muluneh Alemu (2012). Financial Inclusion Buttress incomes, assets, reduce vulnerability to shocks: Birritu 2012. No 30.

Mwaura, D. (2005). Factors affecting the performance of Saving and Credit Cooperative Societies in Kenya: A case study of Afya Cooperative Societies.

Nalusiba D.N. (2019). Outreach and sustainability of savings and credit cooperative organizations (Saccos) in Uganda. Thesis submitted to Makerere University

Nara, H.J. (2013). Outreach and Sustainability of Nepalese Microfinance Institutions, Centre for Empowerment and Development, Kathmandu, Nepal.

Nigusie Dibissa (2015). Determinants of Saving and Credit cooperative societies outreach in Addis Ababa, Ethiopia: Addis Ababa University, Ethiopia. http://ocalhost:80/xmlui/handle/123456789/13640

Nyamsogoro, G. (2010). Microfinance Institutions in Tanzania: A Review of Growth and Performance Trends. The Accountant Journal, 26(3), 3-16.

Okumu,L.J, (2007). The microfinance industry in Uganda: sustainability, outreach and regulation; unpublished PHD dissertation; University of Stevenbosch.

Olivares-Polanco F. (2005). Commercializing microfinance and deepening outreach? Empirical evidence from Latin America. Journal of Microfinance 7(2):38-40

Osoti, R.N. (2014). Effect of the growth of savings and credit co-operative societies' front office services activity on demand for credit by members. MBA Thesis, University of Nairobi. http://erepository.uonbi.ac.ke/bitstream/handle/11295/75252/

Paxton J. (2002). Depth of Outreach and its Relation to the Sustainability of Microfinance Institutions. Savings and Development, Giordano Dell'Amore Foundation.

Quayes, S. (2012). Depth of outreach and financial sustainability of microfinance institutions. Applied Economics, 2012, 44, 3421-3433.

Schreiner, M. (2002). Aspects of outreach: a framework for discussion of the social benefits of microfinance. Journal of International Development. Vol. 14.

Sebhatu, K.T. (2011). Management of Savings and Credit Cooperatives from the Perspective of Outreach and 
Sustainability: Evidence from Southern Tigrai of Ethiopia. Research Journal of Finance and Accounting, 2(7/8), 2011.

Ssebaale Mohammed (2011). Financing Strategies, Financial Sustainability and Outreach of Saccos in Uganda. Unpublished Master's Thesis, Makerere University.

Tavanti, M. (2013). Before microfinance: The social value of micro savings in Vincentian poverty reduction. Journal of Business Ethics, 112(4), 697-706.

Tilahun Aemiro (2013). Determinants of Financial Sustainability of Microfinance Institutions in East Africa

Toli J. (2013). Analysis of Savings and Credit Cooperative Societies Financial Services in Addis Ababa. Master's thesis, Addis Ababa University, 2013

Tucker, M. and Miles, G. (2004). Financial performance of selected microfinance institutions: benchmarking progress to sustainability. Journal of Microfinance 3(2): 41-54.

Turto Turtiainen (2008). Financial cooperatives and rural outreach in developing countries: a tool to involve rural poor in economic life. A paper presented at ICA Research Conference, Trento.

USAID. (2006). Evaluating Microfinance Institutions Social Performance: A Measurement Tool. Micro Report No. 35, USA: USAID.

Vijeta Singh and Puja Padhi (2019). Factors Influencing Outreach Performance of Microfinance Sector in India. Asia-Pacific Journal of Management Research and Innovation 15(4) 162-176, 2019

WOCCU (2011). The guiding principles for effective prudential supervision of cooperative financial institutions. Madison, USA: Author.

Wolday Ameha (2002). Review of micro finance industry in Ethiopia: regulatory frameworks and performance, Occasional Papers, Addis Ababa, Ethiopia.

Woller, G. and Schreiner,M. (2002). Poverty lending, financial self-sufficiency and six aspects of outreach. Working paper, Washington, DC, USA.

Michael J. V. Woolcock (2006). Learning from failures in SACCO: What unsuccessful cases tell us how group based programs work", American Journal of Economics and Sociology 58(1)

World Bank (2003). Rural Financial Services: Implementing the Bank's Strategy to Reach the Rural Poor. Report No. 26030.

Zerai B. and Rani L. (2012). Is There a Tradeoff between Outreach and Sustainability of Micro finance institutions? Evidence from Indian Microfinance Institutions (MFIs), European Journal of Business and Management, 4(2), PP: $90-9$

\section{Appendixes}

Appendix 1

Multi-collinierity test for FSS and ROA

\begin{tabular}{lll}
\hline Variable & VIF & $1 /$ VIF \\
\hline GLA & 1.96 & 0.509692 \\
ALS & 1.62 & 0.615442 \\
NAB & 1.55 & 0.645049 \\
CoOR & 1.35 & 0.741325 \\
MGE & 1.27 & 0.785979 \\
WB & 1.25 & 0.798541 \\
OPE & 1.07 & 0.935532 \\
\hline Mean VIF & 1.44 & \\
\hline
\end{tabular}

Appendix $2 a$

Heteroskedasticity test for FSS

Breusch-Pagan / Cook-Weisberg test for heteroskedasticity

Ho: Constant variance

Variables: fitted values of FSS

chi2 $(1)=3.12$

Prob $>$ chi $2=0.0775$ 
Appendix $2 b$

Heteroskedasticity test for ROA

Breusch-Pagan / Cook-Weisberg test for heteroskedasticity

Ho: Constant variance

Variables: fitted values of ROA

$\operatorname{chi} 2(1)=3.16$

Prob $>$ chi $2=0.0756$

Appendix $3 a$

Model specification test for FSS

Breusch and Pagan Lagrangian multiplier test for random effects

$\mathrm{FSS}[\mathrm{YEAR}, \mathrm{t}]=\mathrm{Xb}+\mathrm{u}[\mathrm{YEAR}]+\mathrm{e}[\mathrm{YEAR}, \mathrm{t}]$

Estimated results:

Test: $\operatorname{Var}(\mathrm{u})=0$

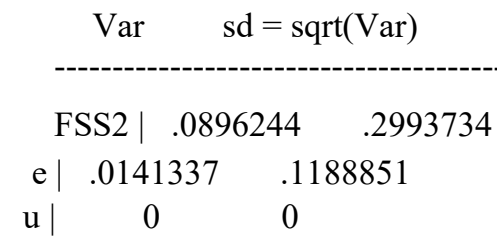

chibar2 $(01)=0.00$

Prob $>$ chibar $2=1.0000$

Appendix $3 b$

Model specification test for ROA

Breusch and Pagan Lagrangian multiplier test for random effects

$\mathrm{ROA}[\mathrm{YEAR}, \mathrm{t}]=\mathrm{Xb}+\mathrm{u}[\mathrm{YEAR}]+\mathrm{e}[\mathrm{YEAR}, \mathrm{t}]$

Estimated results:

Var $\quad$ sd $=$ sqrt(Var)

ROA | .0769093.2773253

e | .0303776 .1742918

u $\quad 0 \quad 0$

Test: $\operatorname{Var}(\mathrm{u})=0$

chibar2(01) $=0.00$

Prob $>$ chibar $2=1.0000$ 